\title{
Analisis Pengaruh Citra Lembaga, Kualitas Layanan dan Religiusitas terhadap Keputusan Muzaki Membaya Zakat dengan Minat sebagai Variabel Moderating (Studi Kasus Pada LazisMu Cabang Suruh)
}

\author{
Iin Sofiyani \\ Pascasarjana IAIN Salatiga \\ sofiyaniiin@gmail.com
}

\section{Agus Kristiyono}

SMP Islam Ar-Rahmah Suruh

krizano.smanta@gmail.com

\begin{abstract}
Abstrak The purpose of this research is to determine the effect of institutional image, service quality, and religiosity, on the decision of Muzaki to pay zakat in LazisMu, using interest as a moderating variable. The research was conducted at Lazis Mu sub district suruh, semarang regency. The population of this quantitative research is muzaki LazisMu in subdistrict Suruh, Semarang Regency with 112 persons. This research is classified askuantitatif. The sample is determined by using a simple random sampling technique. The analytical method used in this research is linear regression analysis using SPSS. Test is being use to collect data in questionnaire, literature review and documentation Before test give to real samples, the test was tested using validity and reliability. The data analysis techniques in this research use descriptive statistical analysis, test classical assumptionsand multiple linear regression. The results of this research stated that institutional image and religiosity are not influenced by the decision of muzaki to pay zakat, while the quality of service affected the decision of muzaki to pay zakat on LazisMu. The research shows that interest moderates the influence of institutional image, service quality, and religiosity, on the decision of muzaki to pay zakat at LazisMu Branch Suruh.

Kata Kunci citra lembaga, kualitas layanan, religiusitas, minat, keputusan.
\end{abstract}

\section{PENDAHULUAN}

Pengelolaan zakat di Indonesia telah diatur dalam UU Nomor 38 Tahun 1999 yaitu mengatur segala kegiatan yang berhubungan dengan perencanaan, pengorganisasian, pelaksanaan dan pengawasan terhadap pengumpulan dan pendistribusian serta pendayagunaan terhadap dana zakat. Menurut UU Republik Indonesia Nomor 38 Tahun 1999 keberadaan zakat sangat penting, dikarenakan dengan adanya pengelolaan zakat dapat meningkatkan pelayanan masyarakat dalam menunaikan zakat sesuai dengan 
tuntunan agama, meningkatkan fungsi dan peran keagamaan dalam mewujudkan kesejahteraan masyarakat dan keadilan sosial, serta meningkatkan hasil dan daya guna zakat. Akan tetapi UU Nomor 38 tahun 1999 tentang pengelolaan zakat ini dirasa masih kurang optimal dengan perkembangan zakat di Indonesia, oleh karena itu DPR-RI mengesahkan UU No 23 tahun 2011 untuk menggantikan UU Nomor 38 tahun 1999 untuk mempermudah kegiatan pengelolaan zakat yang terus berkembang di Indonesia dan meningkatkan pelayanan bagi masyarakat dalam menunaikan zakat sesuai dengan tuntunan agama (Kamaruddin, 2015).

Di dalam UU No 23 tahun 2011 Pasal 17 menyatakan bahwa untuk membantu BAZNAS dalam pelaksanaan,pengumpulan, pendistribusian, dan pendayagunaan zakat, masyarakat dapat membentuk Lembaga Amil Zakat (LAZ). Namun banyak masyarakat yang masih kurang memahami dengan adanya lembaga zakat, sehingga muzaki menyalurkan zakat secara langsung atau ke masjid-masjid terdekat. Para muzaki ini merasa sudah menyalurkan zakat kepada mustahik, padahal ternyata yang menerima bukan mustahik yang sesungguhnya, hanya karena kedekatan emosi maka ia memberikan zakat kepadanya. Misalnya disalurkan kepada kerabatnya sendiri, yang menurut anggapannya sudah temasuk kategori mustahik, padahal jika dibandingkan dengan orang yang berada dilingkungan sekitarnya, masih banyak orang-orang yang lebih berhak untuk menerimanya sebab lebih fakir, lebih miskin, dan lebih menderita dibanding dengan kerabatnya tersebut (Kanji, 2011). Berdasarkan fakta yang ada dapat dikatakan bahwa jika muzaki menyalurkan zakat secara langsung kepada mustahik atau tanpa melalui lembaga zakat kemungkinan penyaluran tersebut tidak tepat sasaran.

Meskipun demikian masih ada sebagian kecil masyarakat yang sudah memahami keberadaan LAZ atau BAZ. Di Indonesia terdapat dua lembaga pengelola zakat. Lembaga yang dikelola pemerintah (Badan Amil Zakat) dan non pemerintah (Lembaga Amil Zakat). Non pemerintah dikelola oleh yayasan atau organisasi yang telah disyahkan oleh Pemerintah diantaranya Dompet Dhuafa, Rumah Zakat Indonesia, LAZISMU, LAZISNU dan yang lainnya.

LAZ yang dipilih dalam penelitian ini adalah LAZIS Mu. Ada beberapa alasan dalam pemilihanLAZIS Musebagai tempat penelitian. Pertama Lazis mu merupakan salah satu LAZ yang sudah diakui pemerintah sejak tahun 2002. Selain itu dalam pengelolaannya LAZIS Mu Pengelolaan yang dijalankan lazismu adalah pengelolaan dengan sistem modern, namun tidak seluruhnya manajemen yang digunakan lazismu dengan sistem modern. Dalam hal ini ada beberapa yang kefokusan yang mencakup didalamnya yaitu, pada manajemen pengelolaan, sumber dana, dan pendistribusian. Manajemen pengelolaan yaitu; tentang kedudukan, prinsip, struktural, tugas dan fungsi, tujuan, visi dan misi, legalitas, dan sebagainya. Sumber dana yaitu tentang sumber keuangan, pembayaran, dan pemungutan. Dalam sumber dana ZIS Lazismu adalah segala macam dan jenis zakat, infaq, shadaqah, dan dana keagamaan lainnya seperti qurban, wakaf, hibah, dan lain sebagainya. Kemudian pembayaran dan pemungutan ada dua jenis yaitu; dengan cara digital (online) dan langsung yaitu dengan cara memanggil pihak petugas Lazismu untuk menjemput dana ZIS, dan mendatangi kantor lazismu untuk pembayaran ZIS. Dari kedua cara tersebut cara yang pertama masuk sebagai sistem modern. Pendistribusian pada Lazismu ada lima bidang program yaitu bidang pendidikan, kesehatan, ekonomi, dakwah dan sosial kemanusiaan, dengan demikian pendistrbusian pada Lazismu termasuk kedalam sistem modern dengan bentuk penyaluran yang 
progresif, produktif, dan juga tidak terlepas dari Konsumtif (Nur'aini, 2015). Ketiga, di tahun 2019 LAZIS Mu mendapat award lembaga filantropi peduli Ekonomi Umat dari MUI. Potensi Zakat di LazisMu Cabang Suruh sebenarnya sangat besar jika semua warga Muhammadiyah dan semua yang bekerja di Amal Usaha Muhammadiyah Menyalurkan Zakatnya di LazisMu cabang Suruh.Dengan adanya penelitian di tingkat kecamatan diharapkan mampu memberikan dorongan kepada masyarakat untuk menyalurkan zakatnya melalui LAZ.

\section{LANDASAN TEORI}

Aspek-aspek yang terdapat dalam minat menurut Lucas dan Britt adalah ketertarikan (interest) yang menunjukkan adanya pemusatan perhatian dan perasaan senang. keinginan (desire) ditunjukkan dengan adanya keinginan memiliki, keyakinan (conviction) ditunjukkan dengan adanya perasaan percaya diri individu terhadap kualitas, daya guna, dan keuntungan dari produk yang akan dibeli (Hanifah, 2015) Menurut Shirley Harrison, citra perusahaan meliputi empat elemen sebagai berikut: a). personality keseluruhan karakteristik perusahaaan yang dipahami public sasaran seperti perusahaan yang dapat dipercaya, perusahaan mempunyai tanggung jawab sosial, b). reputation, hal yang dilakukan perusahaan dan diyakini publik sasaran berdasarkan pengalaman sendiri maupun pihak lain, seperti kinerja keamanan transaksi sebuah bank, c). value, nilai-nilai yang dimiliki perusahaan dengan kata lain budaya perusahaan seperti sikap manajemen yang peduli terhadap pelanggan, karyawan yang cepat tanggap terhadap permintaan maupun keluhan pelanggan, d). Corporate Identity, adalah komponen-komponern yang mempermudah mengenal public sasaran terhadap perusahaan seperti logo, warna, dan slogan (Hanifah, 2015)

Menurut Parasuraman, dalam mengevaluasi jasa yang bersifat intangible, konsumen umumnya menggunakan beberapa dimensi sebagai berikikut a). Bukti Langsung (Tengible). Bukti langsung meliputi fisik, perlengakapan, pegawai, dan sarana komunikasi, b). Kehandalan (Realibility). Kehandalan yakni kemampua memberikan pelayanan yang dijanjikan dengan segera, akurat, dan memuaskan, c). Daya Tanggap (Responsiveness). Tanggapan yaitu keinginan para staf dan karyawan untuk membantu para pelanggan dan memberikan pelayanan dengan tanggap, d). Jaminan (Assurance). Jaminan menyangkut pengetahuan, kemampuan, kesopanan, dan sifat dapat dipercaya yang dimiliki para staf, bebas dari bahaya, risiko atau keraguan, e). Empati (Emphaty). Empati meliputi kemudahan dalam melakukan hubungan, komunikasi yang baik, perhatian pribadi, dan memahami kebutuhan pelanggan (Tjiptono, 2006)

Menurut Glock \& Stack dalam Djamaludin Ancok ada lima dimensi religiusitas yaitu : a). Dimensi keyakinan, dimensi ini berisi pengharapan dimana orang religius berpegang teguh pada pandangan teologis tertentu dan mengakui kebenaran doktrin tersebut, b). Dimensi praktik agama. Dimensi ini mencakup perilaku ketaatan dan hal-hal yang menunjukkan komitmen terhadap agama yang dianutnya. Praktik-praktik keagamaan ini terdiri dari dua kelas penting yaitu ritual dan ketaatan, c). Dimensi pengalaman. Dimensi ini berisikan dan memperhatikan fakta bahwa semua agama mengandung pengharapan tertentu, meski tidak tepat jika dikatakan bahwa seseorang yang beragama dengan baik pada suatu waktu akan mencapai pengetahuan subjektif dan langsung mengenai kenyataan terakhir, e) Dimensi pengetahuan agama. Dimensi ini mengacu kepada harapan bahwa orang-orang yang beragama paling tidak memiliki sejumlah mengenai dasar, 
keyakinan, ritus, kitab suci, dan tradisi, f). Dimensi pengamalan atau konsekuensi. Dimensi ini mengacu pada identifikasi akibat-akibat keyakinan keagamaan, praktik, pengalaman, dan pengetahuan (Ancok, 1994)

\section{METODOLOGI PENELITIAN}

Jenis penelitian ini adalah penelitian kuantitatif. Populasi dalam penelitian ini adalah seluruh muzaki LazisMu yang berada di Kecamatan Suruh. Sampel dalam penelitian ini diambil dari muzaki dengan menggunakan teknik simple random sampling. Penentuan jumlah sampel menggunakan rumus Slovin. Terdapat 88 kuisioner yang di olah dalam penelitian ini. Metode pengumpulan data primer yang di pakai adalah dengan menggunakan kuisioner. Metode analisis yang digunakan dalam penelitian ini menggunakan analisis regresi linear dengan bantuan SPSS.

\section{HASIL PENELITIAN}

Pengaruh citra lembaga, kualitas layanan, dan religiusitas terhadap keputusan muzaki membayar zakat dapat dianalisis menggunakan uji-T dengan melihat signifikansinya. Adapun hasil uji-T dapat dilihat pada table.1 dibawah ini.

Tabel 1. Output Uji-T

Coefficients

\begin{tabular}{|l|c|c|c|c|c|}
\hline \multirow{2}{*}{ Model } & \multicolumn{2}{|c|}{ Unstandard Coefficients } & $\begin{array}{c}\text { Standardized } \\
\text { Coefficients }\end{array}$ & $\mathrm{t}$ & sig \\
\cline { 2 - 4 } & $\mathrm{B}$ & Std Error & Beta & & \\
\hline 1 (Constant) & 11.831 & 2.805 & & 4218 & .000 \\
Citra Lembaga & -155 & .077 & -.280 & -2.027 & .046 \\
Kualitas & -337 & .049 & .963 & 6.910 & .000 \\
layanan & -425 & .122 & -.358 & -3.473 & .001 \\
Religiusitas & & & & & \\
\hline
\end{tabular}

a. Dependent Variable : Keputusan

Bagian hasil berisi data hasil penelitian dari permasalahan

Berdasarkan table.1 diketahui bahwa citra lembaga berpengaruh terhadap keputusan muzaki membayar zakat di Lazis Mu Cabang Suruh, hal ini dapat dilihat dari nilai signifikan sebesar $0.046<0.05$ akan tetapi nilai $\mathrm{t}=-2,027$, maka dapat disimpulkan bahwa citra lembaga tidak berpengaruh terhadap keputusan muzaki membayar zakat. Hasil ini menjelaskan bahwa citra lembaga tidak dapat menjadi tambahan referensi bagi muzaki dalam menyalurkan zakatnya. Lazis Mu Suruh dapat dikatakan mempunyai citra lembaga yang baik, sehinggga masyarakat sudah tidak lagi mempertimbangkan dalam memutuskan untuk berzakat. Bagi muzaki citra lembaga yang baik belum tentu membuat mereka berkeinginan untuk berzakat di LazisMu. Sebagian muzaki lebih mempertimbangkan perihal lainnya, seperti kualitas produk, rekomendasi teman atau sesuai dengan keinginan dirinya sendiri. Hal ini sejalan dengan penelitian Nurhayati, (Nurhayati, 2017) dan (Molanda, 2018).

Berdasarkan table.1 diketahui bahwa kualitas layanan berpengaruh terhadap keputusan muzaki membayar zakat di LazisMu cabang Suruh, hal ini dapat dilihat dari nilai signifikansi sebesar 0.00 lebih kecil dari 0.05, maka dapat disimpulkan bahwa kualitas 
layanan berpengaruh terhadap keputusan muzaki membayar zakat. Penelitian ini sejalan dengan penelitian yang dilakukan (Satria Darma, 2015) dan (Andi, 2015) yaitu kualitas layanan juga berpengaruh terhadap keputusan membayar zakat.

LazisMu Cabang Suruh dalam melayani muzaki dengan menerapkan sistem jemput bola yaitu sistem amil mendatangi para muzaki yang akan membayarkan zakatnya, sehingga memudahkan para muzaki untuk menyalurkan zakatnya.

Berdasarkan table. 1 nilai signifikansi variabel religiusitas sebesar 0.01 lebih kecil dari 0.05 akan tetapi nilai $\mathrm{t}=-3,473$ maka dapat disimpulkan bahwa religiusitas tidak berpengaruh terhadap keputusan muzaki membayar zakat di Lazis Mu Cabang Suruh. Hal ini sejalan dengan penelitian (Daniati, 2015) dan (Farah,2017). Sehingga dapat dikatakan bahwa semakin tinggi tingkat religiusitas tidak mempengaruhi keputusan muzaki membayar zakat di Lazis Mu Cabang Suruh. Religiusitas itu sendiri dipengaruhi oleh beberapa faktor yaitu keyakinan, pengamalan, penghayatan, pengetahuan, dan konsekuensi.

Adapun yang menjadi penyebab lain, yaitu semakin tinggi tingkat religiusitas seseorang belum tentu memiliki jiwa sosial yang tinggi, yang menimbulkan kesadaran diri. Hal ini dikarenakan pengaruh lingkungan yang terdiri dari berbagai keyakinan agama, serta tinggi rendahnya religiusitas belum tentu menjamin baik buruknya jiwa sosial seseorang (Gurning, 2014). Apabila seseorang telah baik tingkat religiusitasnya belum menjamin baiknya tingkat kepedulian sosialnya.

Analisis jalur digunakan untuk mengetahui pengaruh citra lembaga, kualitas layanan, dan religiusitas terhadap keputusan muzaki membayar zakat dengan minat sebagai variable moderating. Adapun analisi jalur setiap variable disajikan dalam table 2, 3, 4, 5,6 dan 7 dibawah ini.

Tabel 2. Output R Square analisis jalur pengaruh citra lembaga terhadap keputusan muzaki membayar zakat.

\begin{tabular}{|c|r|r|r|r|}
\hline \multicolumn{5}{|c|}{ Model Summary } \\
\hline Model & R & R Square & $\begin{array}{c}\text { Adjusted R } \\
\text { Square }\end{array}$ & $\begin{array}{c}\text { Std. Error of } \\
\text { the Estimate }\end{array}$ \\
\hline 1 & $.280^{\mathrm{a}}$ & 0.79 & 0.68 & 2.053 \\
\hline
\end{tabular}

a. Predictors (Constant), Citra Lembaga

Tabel 3. Output R Square analisis jalur pengaruh citra lembaga terhadap keputusan muzaki membayar zakat dengan minat sebagai variable moderating

\begin{tabular}{|c|r|r|r|r|}
\hline Model & R & R Square & $\begin{array}{l}\text { Adjusted R } \\
\text { Square }\end{array}$ & $\begin{array}{l}\text { Std. Error of } \\
\text { the Estimate }\end{array}$ \\
\hline 1 & $.767^{\mathrm{a}}$ & .588 & .573 & 1.389 \\
\hline
\end{tabular}

a. Predictors (Constant), MODERATING, Citra Lembaga, Minat

Berdasarkan table. 2 dan 3 nilai R square pada persamaan regresi pertama sebesar 0.079 dapat dikatakan bahwa variabel citra lembaga berpengaruh terhadap keputusan sebesar $7,9 \%$. setelah adanya variabel moderasi pada persamaan regresi kedua nilai RSquare 
tersebut meningkat menjadi 58.8\% . Dengan demikian dapat disimpulkan bahwa keberadaan variabel minat sebagai variabel moderasi dapat memperkuat atau meingkatkan pengaruh variabel citra lembaga terhadap keputusan. Hal ini sejalan dengan penelitian (Bagja, 2014), (Ritaratama, 2013) dan (Retno, 2019) yang menyatakan bahwa minat berpengaruh terhadap keputusan.

Tabel 4. Ouput Rsquare analisis pengaruh kualitas layanan terhadap keputusan muzaki membayar zakat.

Model Summary

\begin{tabular}{|c|r|r|r|r|}
\hline Model & \multicolumn{1}{|c|}{$\mathrm{R}$} & R Square & \multicolumn{1}{|c|}{$\begin{array}{c}\text { Adjusted R } \\
\text { Square }\end{array}$} & $\begin{array}{l}\text { Std. Error of } \\
\text { the Estimate }\end{array}$ \\
\hline 1 & $.537^{\mathrm{a}}$ & .289 & .280 & 1.804 \\
\hline
\end{tabular}

a. Predictors (Constant), Kualitas Layanan

Tabel 5. Ouput Rsquare analisis jalur pengaruh kualitas layanan terhadap keputusan muzaki membayar zakat dengan minat sebagai variable moderating.

\begin{tabular}{|c|r|r|r|r|}
\hline \multicolumn{5}{|c|}{ Model Summary } \\
\hline Model & R & R Square & $\begin{array}{c}\text { Adjusted R } \\
\text { Square }\end{array}$ & $\begin{array}{c}\text { Std. Error of } \\
\text { the Estimate }\end{array}$ \\
\hline 1 & $.765^{\mathrm{a}}$ & .586 & .571 & 1.393 \\
\hline
\end{tabular}

a. Predictors (Constant), MODERATING Kualitas Layanan, Minat

Berdasarkan table 4 dan 5 nilai Rsquare pada persamaan regresi pertama sebesar 0.289 dapat dikatakan bahwa variabel kualitas layanan berpengaruh terhadap keputusan sebesar $28,9 \%$, setelah adanya variabel moderasi pada persamaan regresi kedua nilai Rsquare tersebut meningkat menjadi 58.6\%. Dengan demikian didapatkan keberadaan variabel minat sebagai variabel moderasi dapat memperkuat pengaruh variabel kualitas layanan terhadap keputusan. Hal ini sejalan dengan penelitian (Bagja, 2014), (Ritaratama, 2013) dan (Retno, 2019) yang menyatakan bahwa minat berpengaruh terhadap keputusan

Tabel 6. Ouput Rsquare analisis jalur pengaruh citra lembaga terhadap keputusan muzaki membayar zakat.

\begin{tabular}{|c|r|r|r|r|}
\hline Model & R & R Square & $\begin{array}{c}\text { Adjusted R } \\
\text { Square }\end{array}$ & $\begin{array}{l}\text { Std. Error of } \\
\text { the Estimate }\end{array}$ \\
\hline 1 & $.035^{\mathrm{a}}$ & .001 & -.00 & 2.138 \\
\hline
\end{tabular}

a. Predictors (Constant), Religiusitas.

Tabel 7. Ouput Rsquare analisis jalur religiusitas terhadap keputusan muzaki membayar zakat dengan minat sebagai variable moderating.

\begin{tabular}{|c|r|r|r|r|}
\hline Model & R & R Square & $\begin{array}{c}\text { Adjusted R } \\
\text { Square }\end{array}$ & $\begin{array}{l}\text { Std. Error of } \\
\text { the Estimate }\end{array}$ \\
\hline 1 & $.035^{\mathrm{a}}$ & .001 & -.000 & 2.138 \\
\hline
\end{tabular}

a. Predictors (Constant), Religiusitas 
Berdasarkan table 6 dan 7 nilai Rsquare sebesar 0.001, artinya bahwa variabel religiusitas berpengaruh terhadap keputusan sebesar $0.1 \%$, setelah adanya variabel moderasi pada persamaan regresi kedua nilai Rsquare tersebut meningkat menjadi 63,9\%. Sehingga didapatkan bahwa keberadaan variabel minat sebagai variabel moderasi dapat meingkatkan pengaruh variabel religiusitas terhadap keputusan. Hal ini sejalan dengan penelitian (Bagja, 2014), (Ritaratama, 2013) dan (Retno, 2019) yang menyatakan bahwa minat berpengaruh terhadap keputusan

\section{KESIMPULAN}

Kesimpulan penelitian menunjukkan bahwa citra lembaga dan religiusitas tidak berpengaruh terhadap keputusan muzaki membayar zakat, sedangkan kualitas layanan berpengaruh terhadap keputusan muzaki membayar zakat di Lazis $\mathrm{Mu}$. Penelitian menunjukkan bahwa minat memoderasi pengaruh citra lembaga, kualitas layanan, religiusitas, terhadap keputusan muzaki membayar zakat di LazisMu Cabang Suruh

\section{DAFTAR PUSTAKA}

Ancok, Djamaludin, Fuat Nashori Suroso. (1994) Psikologi Islam:Solusi Islam Atas Problem-Problem Psikologi, Yogyakarta:Pustaka Pelajar.

Daniati, Tesa, (2017). "Pengaruh Religiusitas Muzaki, Akuntabilitas dan Kredibilitas Lembaga Amil Zakat Terhadap Keputusan Membayar Zakat Di Lembaga Amil Zakat Periode 2015 - 2017”, Publikasi Ilmiah,

Deisy, Molanda Joyce Lapian, dan Yunita Mandagie, (2018). "Analisis Citra Merek, Harga Produk dan Kualitas terhadap keputusan pembelian handphone samsung pada seluruh gerai-gerai seluler di IT Center Manado", Jurnal EMBA,

Farah, Jama Mohamed Sereye, yusuf Haji Othman, dan Mohammed Omar, (2017) "The Influence of Attitude, Religiosity, and Preception towards Law Enforcement on Intention towards Compliance Behaviour of Income Zakat among KUIN Staf in Kedah Malaysia", International Journal of Muamalat, December vol.1 Issue 1,

Fauzia, Diah Retno Sufi, Edriana Pangestuti, Aniesa Samira Bafadhal, (2019) "Pengaruh Religiusitas, Sertifikat Halal, Bahan Produk Terhadap Minat Beli dan Keputusan Pembelian, Jurnal Administrasi Bisnis (JAB), Vol.66 No. 1, Januari

Gurning, Herfita Rizki Hasanah \& Ritonga, Haroni Doli Hamoraon,(2014) "Analisis Tingkat Kesadaran Masyarakat Kecamatan Medan Baru dalam Membayar Zakat", Jurnal Ekonomi dan Keuangan, Volume 3, Nomor 7 hlm. 490-504.

Hafizi. (2016). "Modernisasi Pengelolaan Zakat di LAZISMU”, Naskah Publikasi, Universitas Muhammadiyah Surakarta, 2016. 
Kanji, Lusiana H “Aktor Determinan Motivasi Membayar Zakat”. (2015). Jurnal Online, 2011.

Kamaruddin, Andi Martina , Zamrudin Hasid, Yuningsih,"Faktor-faktor yang mempengaruhi keputusan berzakat profesi dan loyalitas Muzzaki terhadap Laz Rumah Zakat Kota Semarang", Jurnal eksekutif, Volume12 No. 2 Desember,

Nur'aini, Hanifah, M. Rasyid Ridla, (2015). "Pengaruh Kulaitas Pelayanan,Citra Lembaga dan religiusitas Terhadap Minat Muzaki Untuk Menyalurkan Zakat profesi (Studi di Pos Keadilan Peduli UmmatYogyakarta),Jurnal MD,

Nurhayati, Siti. (2017). "Pengaruh Citra Merek, Harga dan promosi terhadap keputusan pembelian Handphon Samsung di Yogyakarta, JBMA, Vo. IV.

Ritaratama, (2013). "Analysis Perceived Quality, Brand Image and value on Buying Interest and Implications for Purchasing Decisions (Case Study on Singtel Celuler Card in Malaysia), International Journal Of Behavior Marketing, vol 5.

Sumantri, Bagja (2014), "Pengaruh Kualitas Pelayanan dan Produk Pembiayaan Terhadap Minat dan Keputusan Menjadi Nasabah di Bank Syariah", Jurnal Economia, Volume 10 Nomor 2, 2014.

Tjiptono, Fandy, (2006). Manajemen Pelayanan Jasa, Yogyakarta : Andi, 